\title{
A Rare Odontogenic Cyst in an Uncommon Area: Case Report and Review of the Literature
}

\section{Um cisto odontogênico raro em uma área incomum: Relato de caso e revisão da literatura}

\author{
Samira Behrad ${ }^{1(1)}$ Isa Safari ${ }^{20}$ Shabnam Sohanian ${ }^{10}$ Arash Ghanbarzadegan ${ }^{3(1)}$ \\ ${ }^{1}$ Oral and Maxillofacial Pathology Department, Dental School, \\ Semnan University of Medical Sciences, Semnan, Iran \\ 2 Orthodontics Department, Dental School, Semnan University of \\ Medical Sciences, Semnan, Iran \\ ${ }^{3}$ Australian Research Centre for Population Oral Health (ARCPOH), \\ Adelaide Dental School, University of Adelaide, Adelaide, South \\ Australia, Australia \\ J Coloproctol 2021;41(1):83-86. \\ Address for correspondence Shabnam Sohanian, 17 Shahrivar Blvd., \\ Oral and Maxillofacial Pathology Department, Dental School, Semnan \\ University of Medical Sciences, Semnan, Iran \\ (e-mail: dr.sh.sohanian@gmail.com).
}

\section{Abstract \\ Keywords \\ - odontogenic cysts \\ - odontogenic tumors \\ - jaw cysts \\ - bone cysts}

\section{Resumo}

received

June 24, 2020

accepted

August 23, 2020
Objective Orthokeratinized odontogenic cyst is a rare developmental odontogenic cyst of the jaws. It is a less aggressive intraosseous cyst identified by an orthokeratinized epithelium.

Case Report A 50-year-old male patient with the chief complaint of swelling in the anterior part of his face, and, intraorally, there was diffuse swelling in the palatal cortex. On panoramic radiography, there was a well-defined unilocular radiolucency on the right side of the maxilla and palatal cortical expansion, and thinning of the buccal and palatal cortexes was observed. The histopathological examination revealed a pathologic cyst that was lined by a thick orthokeratinized epithelium. Therefore, the diagnosis was orthokeratinized odontogenic cyst.

Conclusion The orthokeratinized odontogenic cyst displays characteristic clinical, histopathological, and biological features that differ significantly from those of keratocystic odontogenic tumor (KCOT), but it has a better prognosis and lower recurrence rate. Thus, other radiolucent lesions of the jaws, including keratocystic odontogenic tumor (KCOT), must be considered in the differential diagnosis.

Objetivo O cisto odontogênico ortoceratinizado é um raro cisto odontogênico maxilar. É um cisto intraósseo menos agressivo, identificado por um epitélio ortoceratinizado.

Relato de caso Um paciente do sexo masculino, de 50 anos de idade, com queixa principal de edema na parte anterior da face, e, intraoralmente, havia edema difuso no córtex palatal. Na radiografia panorâmica, havia uma radioluminescência unilocular bem definida no lado direito da maxila e expansão cortical palatina, e desbastamento
DOI https://doi.org/

10.1055/s-0041-1724057. ISSN 2237-9363.

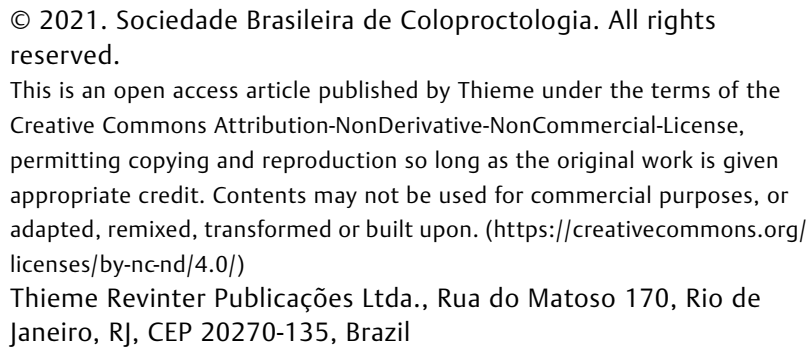

(c) 2021. Sociedade Brasileira de Coloproctologia. All rights reserved.

This is an open access article published by Thieme under the terms of the Creative Commons Attribution-NonDerivative-NonCommercial-License, permitting copying and reproduction so long as the original work is given appropriate credit. Contents may not be used for commercial purposes, or adapted, remixed, transformed or built upon. (https://creativecommons.org/ licenses/by-nc-nd/4.0/)

Thieme Revinter Publicações Ltda., Rua do Matoso 170, Rio de Janeiro, RJ, CEP 20270-135, Brazil 


\author{
Palavras-chave \\ - cistos odontogênicos \\ - tumores \\ odontogênicos \\ - cistos mandibulares \\ - cistos ósseos
}

dos córtex vestibular e palatino. O exame histopatológico revelou cisto patológico revestido por espesso epitélio ortoceratinizado. Logo, o dignóstico foi de cisto odontogênico ortoceratinizado.

Conclusão O cisto odontogênico ortoceratinizado apresenta características clínicas, histopatológicas e biológicas que diferem significativamente das do tumor odontogênico ceratocístico (TOC), mas tem melhor prognóstico e menor taxa de recorrência. Portanto, outras lesões radiolúcidas dos maxilares, incluindo TOC, devem ser consideradas no diagnóstico diferencial.

\section{Introduction}

The orthokeratinized odontogenic cyst (OOC) is an unusual developmental cyst which was previously diagnosed as odontogenic keratocyst (OKC). ${ }^{1}$ Previously, many studies discussed the clinicopathological differences between OKC and OOC. ${ }^{1,2}$ Numerous series of OOCs have been reported with characteristic clinical, histopathological and biological features differ substantially from those of odontogenic keratocysts, as well as demonstrating a better prognosis and lower recurrence rates. ${ }^{3}$ Some studies reported that OKC is a neoplasm, which is preferably called keratocystic odontogenic tumor (KCOT). ${ }^{4}$ According to the World Health Organization classification of head and neck tumors, OOC is not a part of KCOT and should be considered as a distinct entity. ${ }^{1}$ Orthokeratinized odontogenic cyst is a less aggressive intraosseous cyst identified by an orthokeratinized epithelium. ${ }^{3}$ It has been suggested that KCOT may arise from the dental lamina, but $\mathrm{OOC}$ may arise from the oral epithelium under the influence of the dental papilla or only the oral epithelium. ${ }^{4}$

Orthokeratinized odontogenic cysts mainly occur in males during the third and fourth decades of life. ${ }^{5}$ They are located predominantly in the posterior part of the mandible, in the molar and ramus area. ${ }^{1}$ Clinically, they can grow and cause cortical expansion, swelling, and pain, although most of them can be detected incidentally through radiographic check-up. ${ }^{2}$ Radiographically, OOCs may present mostly as a unilocular radiolucency; however, the large cysts might be multilocular. ${ }^{5}$

Histopathologically, the OKC has a prominent granular layer below the keratinized layer. Although the lining epithelium of OOC is generally uniform and thin, it has quite thick orthokeratinized surface layers, resembling an onion skin. ${ }^{1}$ The palisaded basal cell layer and hyperchromatic nuclei, which are predominately seen in OKC, are absent in $\mathrm{OOC}^{3}$ The standard treatment for OOCs is enucleation and curettage. Recurrence of OOCs is rare, differently from the high recurrence rate of KCOTs. ${ }^{5}$ Here, we present the clinical, radiographical, and microscopic findings of a rare $\mathrm{OOC}$ which was found in the anterior part of the maxilla.

\section{Case Report}

A 50-year-old male patient visited the department of oral surgery of the Semnan dental school with a chief complaint of swelling in the anterior part of his face. The patient did not notice it until 2 months prior to the visit. Intraorally, there was a diffuse swelling in the palatal cortex. The patient did not have any systemic disease and looked well and healthy. On panoramic radiography, there was a well-defined unilocular radiolucency on right side of the maxilla, measuring $\sim 3 \times 1.5$ $\times 2.4 \mathrm{~cm}$. Palatal cortical expansion and thinning of buccal and lingual cortexes were seen. There was no evidence of root resorption however loss of lamina dura and periodontal ligament (PDL) widening of incisors was obvious. (-Fig. 1) After obtaining informed consent, an incisional biopsy was done, and the histopathological examination revealed a pathologic cyst that was lined by a thick orthokeratinized epithelium. The wall of the cyst was fibrocolagenized, with a mild lymphocyte infiltration. (- Fig. 2 A, B) Considering the histopathological features, OOC was diagnosed.

\section{Discussion}

Orthokeratinized odontogenic cyst is an uncommon developmental odontogenic cyst which had been previously diagnosed as OKC. ${ }^{1}$ The occurrence of the OOCs is predominant in young adults and show over a 2:1 male-to-female ratio. The lesion occurs more frequently in the mandible than in the maxilla (3:1 ratio), with a tendency to involve the posterior areas of the jaws. ${ }^{2}$ The most common sites were in the mandibular molar and ramus region. ${ }^{2}$ MacDonald et al. (2010), in a systematic review which aimed to evaluate the clinical and radiographic features as well as the frequency of OOC, reported that males are more frequently affected than females, as confirmed by our case. ${ }^{6}$

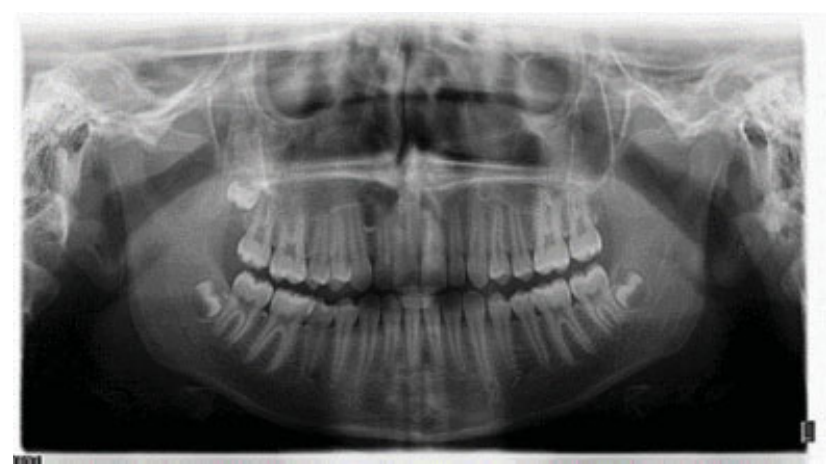

Fig. 1 A well-defined unilocular radiolucency in the right side of the maxilla. 

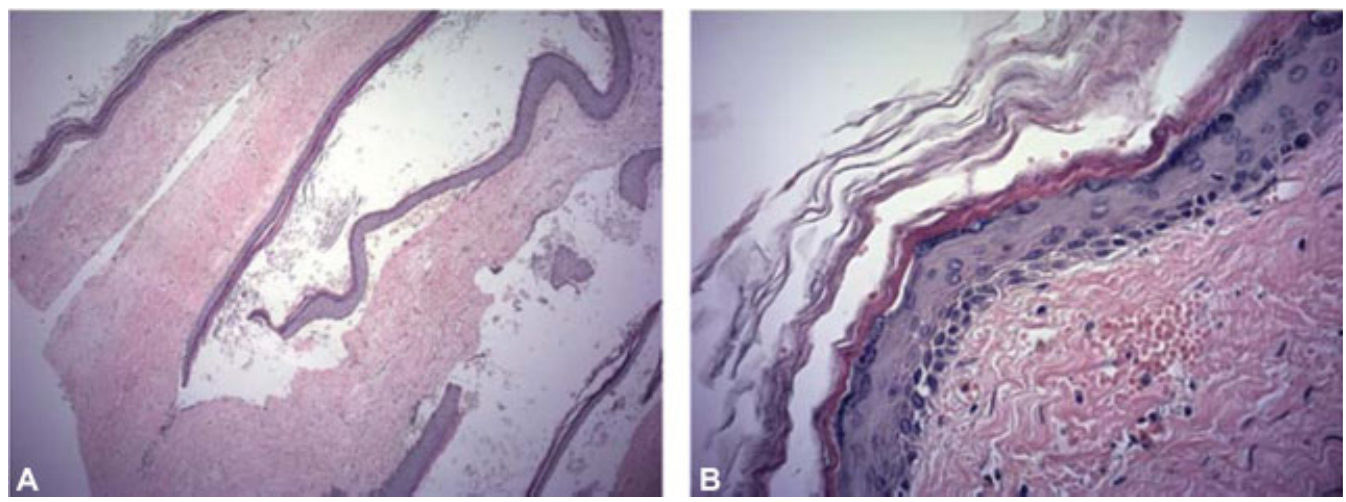

Fig. 2 (A) A pathologic cyst which was lined by a thick orthokeratinized epithelium. The wall of the cyst was fibrocolagenized with a mild lymphocyte infiltration. (H\&E $\times 100)$, (B) The closer histopathological aspect $(H \& E \times 400)$

Table 1 Orthokeratinized odontogenic cysts reported in the English literature

\begin{tabular}{|l|l|l|l|l|l|}
\hline & Author/Year & $\begin{array}{l}\text { MacDonald } \\
(\mathbf{2 0 1 0})^{10}\end{array}$ & $\begin{array}{l}\text { Dong } \\
(\mathbf{2 0 0 9})^{2}\end{array}$ & $\begin{array}{l}\text { MacDonald } \\
(\mathbf{2 0 1 0})^{7}\end{array}$ & $\begin{array}{l}\text { Gonzalez } \\
\text { Galvan(2013) }^{5}\end{array}$ \\
\hline & Number of cases & 192 & 61 & ING & 3 \\
\hline Gender & Male:Female & $127: 65$ & ING & $2: 3$ & $2: 3$ \\
\hline & Mean age & $34: 89$ & ING & $34: 20$ & $33: 6$ \\
\hline Location & Maxilla:Mandible & $43: 104$ & $6: 55$ & $2: 4$ & $0: 3$ \\
\hline Pain & yes:no & $26: 82$ & $13: 48$ & $2: 3$ & $1: 2$ \\
\hline Incidental finding & yes:no & $39: 43$ & ING & $0: 5$ & $1: 2$ \\
\hline Shape & Unilocular:Multilocular & $119: 9$ & $47: 7$ & $3: 2$ & $2: 1$ \\
\hline Root resorption & yes:no & $0: 5$ & ING & $0: 5$ & $0: 3$ \\
\hline Tooth displacement & yes:no & $4: 3$ & ING & $4: 1$ & $1: 2$ \\
\hline Swelling & yes:no & $37: 53$ & $46: 61$ & ING & $2: 1$ \\
\hline & Mean size & ING & $4: 8$ & ING & ING \\
\hline Unerupted tooth & yes:no & $50: 22$ & 27 & $3: 2$ & $2: 1$ \\
\hline Recurrence & yes:no & $7: 158$ & $0: 42$ & ING & ING \\
\hline
\end{tabular}

Abbreviation: ING, Information not given.

Clinically, the OOC exists as a single cyst, shows a predilection for males, and is most often found from the $2^{\text {nd }}$ to the $5^{\text {th }}$ decades of life. ${ }^{6}$ The case presently discussed was that of a 50 -year-old man, confirming this trend. Moreover, MacDonald et al. detailed that in females, the majority of the occurrences are found in the second decade of life. ${ }^{6}$ The manifestation of these lesions in the second decade of women's lives might be related to hormonal elements because this is the decade when menarche usually takes place. ${ }^{4}-$ Table 1 shows all cases of OOC reported in the literature. ( - Table $\mathbf{1}$ )

The OOC affects the mandible twice more often than the maxilla, with a predilection for the most posterior region, ${ }^{7}$ but the present case occurred in the anterior part of the maxilla; therefore, it is remarkable enough to be reported. Dong et al. reported the occurrence rate of OOC in the anterior maxilla $<5 \%^{2}$

Radiographically, OOC usually appears as a well-defined solitary unilocular or multilocular radiolucent lesion. ${ }^{1,3,5}$ Approximately $50 \%$ of OCCs are associated with an unerupted tooth. ${ }^{1}$ It appears most commonly as a dentigerous cyst in the posterior part of the mandible. Unicystic ameloblastoma and KCOT are the lesions that must be considered as differential diagnoses. ${ }^{8}$ Other authors considered malignant tumors and periapical cysts as differential diagnoses. ${ }^{7-10}$ This means that all periapical radiolucencies must be evaluated histopathologically. ${ }^{10}$ The $00 \mathrm{C}$ shows little clinical aggressiveness. A few studies stated that OOCs showed more aggressive signs, such as paresthesia. ${ }^{1}$ Differentiation between KCOT and OOC is essential, with respect to their treatment modalities and due to the high recurrence rate and aggressiveness of KCOT. ${ }^{8}$ Orthokeratinized odontogenic cyst is characterized by an orthokeratinized epithelium with a thickness of 4 to 8 cell layers, with prominent granulosum and low cuboidal basal cells, histologically; as we saw in the case presently discussed. ${ }^{7}$ Orthokeratinized odontogenic cysts can present as periapical radiolucency; however, it has a different prognosis from conventional inflammatory periapical diseases, such as inflammatory cysts, granulomas, and abscesses. ${ }^{9}$ Hence, evaluation of the keratin is mandatory to confirm the diagnosis and estimate patients' prognoses precisely. ${ }^{9}$ 


\section{Conclusion}

The OOC displays characteristic clinical and histopathological features that vary significantly from KCOT, with a lower recurrence rate and better prognosis. It is important to notice that other radiolucent lesions of the jaws must be considered in the differential diagnosis, such as dentigerous cyst, ameloblastoma, and KCOT.

\section{Conflict of Interests}

The authors have no conflict of interests to declare.

\section{References}

1 Dong Q, Pan S, Sun LS, Li TJ. Orthokeratinized odontogenic cyst: a clinicopathologic study of 61 cases. Arch Pathol Lab Med 2010; 134(02):271-275

2 Yoshida H, Onizawa K, Yusa H. Squamous cell carcinoma arising in association with an orthokeratinized odontogenic keratocyst. Report of a case. J Oral Maxillofac Surg 1996;54(05):647-651

3 Vera-Sirera B, Rubio-Martínez L, Forner-Navarro L, Vera-Sempere F. Orthokeratinized odontogenic cysts: a Spanish tertiary care centre study based on HPV DNA detection. Head Face Med 2018;14(01):10
4 Irani S, Dalband M. Orthokeratinized Odontogenic Cyst: An Unusual Histopathological Presentation. Avicenna J Dent Res 2016:1-4

5 Rajalakshmi R, Sreeja C, Vijayalakshmi D, Leelarani V. Orthokeratinised odontogenic cyst mimicking periapical cyst. BMJ Case Rep 2013;2013:1-4

6 MacDonald-Jankowsk DS. Orthokeratinized odontogenic cyst: systematic review - analysis of the included reports. Dentomaxillofac Radiol 2010;39:455-467

7 Byatnal A, Natarajan J, Narayanaswamy V, Radhakrishnan R. Orthokeratinized odontogenic cyst - critical appraisal of a distinct entity. Braz J Oral Sci 2013;12:71-75

8 Sarvaiya B, Vadera H, Sharma V, Bhad K, Patel Z, Thakkar M. Orthokeratinized odontogenic cyst of the mandible: A rare case report with a systematic review. J Int Soc Prev Community Dent 2014;4(01):71-76

9 Silva Servato JP, Cardoso SV, Parreira da Silva MC, Cordeiro MS, Rogério de Faria P, Loyola AM. Orthokeratinized odontogenic cysts presenting as a periapical lesion: report of a case and literature review. J Endod 2014;40(03):455-458

10 Kshirsagar K, Shah S, Kheur S. Orthokeratinized odontogenic keratocyst crossing mandibular midline: A diagnostic dilemma. Med J DY Patil Univ 2014;7:349-353 